\title{
PAUL ARISTE CENTRE FOR INDIGENOUS FINNO-UGRIC PEOPLES AT THE UNIVERSITY OF TARTU HAS BEEN ACTIVE FOR FIVE YEARS (1999-2004)
}

\author{
Kadi Sarv
}

\begin{abstract}
Paul Ariste Centre for Indigenous Finno-Ugric Peoples was established on the initiative of the Kindred Peoples' Programme in autumn 1999. The article provides an overview of the activities of the Ariste centre in the five years it has been active - the scholarship students of the Kindred Peoples' Programme in Estonia, the communication forum SURING established for Finno-Ugric students, seminars on various Finno-Ugric issues, and the participation of the scholarship students of the programme in international academic events. The most consequential work has been done on compiling the online publications on the Mordvin and Komi in cooperation with the Department of Folkloristics of the Estonian Literary Museum and with the involvement of young people of our kinfolk studying in Estonia. Various publications in Finno-Ugric languages have added impetus to the first studies in various fields and to creating and updating academic terminology in native Finno-Ugric languages.
\end{abstract}

Key words: Kindred Peoples' Programme, scholarship students of the Kindred Peoples' Programme, seminars in Finno-Ugric studies, publications and websites on Finno-Ugric issues, Paul Ariste Centre for Indigenous Finno-Ugric Peoples, forum SURING

The Centre for Indigenous Finno-Ugric Peoples was established at the University of Tartu in autumn 1999 on the initiative and with support of the Kindred Peoples' Programme (KPP - a state aid programme for supporting Uralic indigenous languages and cultures (1999-2004)). The centre was named after academician Paul Ariste as a bow to his remarkable contribution in educating intellectuals in the humanities among the kindred peoples - most higher education schools of Finno-Ugric countries have professors who at one time or another have been taught by Ariste. Since 1999, Tõnu Seilenthal has been active as the head of the Ariste centre, and Kadi Sarv as the centre's coordinator.

According to the Kindred Peoples' Programme (http://www.suri.ee/hp) the main aim of the centre is to help students of Finno-Ugric ethnicity who have been invited to Estonia as Kindred Peoples' Programme stipendiaries to adapt here and maintain contact with their homeland; also to prepare the students for academic, economical and political contacts with people of different cultural backgrounds. The programme scholarship students are offered various technological means by the Ariste centre to make their studying easier - photocopying and 
printing study materials and the use of computer, scanner and fax machine. If required, the centre's coordinator provides Estonian language editing for the students' papers, and each student is allowed to make a phone call home at the centre's expense.

The Ariste's centre regularly circulates information about events by advertisements and e-mail, and has also opened a mailing list ugrimugri, intended for fast dissemination of information about Finno-Ugric matters among the kindred peoples and those interested in their cooperation. The centre's home page (http:// www.ut.ee/Ural/ariste) offers information on the Ariste centre and the Kindred Peoples' Programme in Estonian, Russian, and English. The list of students of indigenous Uralic ethnicity contains the name of the student, the academic major he or she is following, and his or her e-mail address. In addition to the library catalogue of the centre, the home page also presents a selection of degree theses defended in 2000-2004 by the stipendiaries of the Kindred Peoples' Programme at the University of Tartu.

Finno-Ugric youth living in Russia have had the opportunity to study in the Estonian schools of higher education since 1991. In the first years their studies were financed by the Finno-Ugric republics. During the years 1994-1998, the FinnoUgric students attending Estonian universities received scholarships from the M. A. Castrén Society from the means of the Finnish Kindred Peoples' Programme. 44 students were granted the A. J. Sjögren's scholarship each year. The Finnish scholarships were cancelled when Estonia launched its own Kindred Peoples' Programme in 1999 (sanctioned by the Government of the Republic of Estonia on May 5, 1998).

The number of Kindred Peoples' Programme stipendiaries has consistently decreased over the years 1999-2004. While in the 1999/2000 academic year the number of young Finno-Ugrians studying in Estonian universities and higher education schools was 110 (Fenno-Ugric Fact Sheet 2000/4 (24)), in autumn 2004 only 55 Finno-Ugric students continued their studies in Estonia. Current stipendiaries of the Kindred Peoples' Programme are studying in five Estonian schools of higher education - 36 at the University of Tartu, 12 at Tallinn University, 4 at the Estonian University of Life Sciences, 2 at the Tallinn University of Technology, and 1 student at the Estonian Academy of Music and Theatre. In the past years, law has become the most popular subject with 11 students ( 3 on the MA level and 1 on the PHD level) out of 55. Law students are followed by the traditional Estonian and Finno-Ugric languages with 9 students, and by psychology, economics, business administration, agriculture, journalism and art history - each represented by 2 students.

The number of positions is related to the number of graduates and those who have returned to their homeland. In spring 2002, the Council of the Kindred Peoples' Programme decided not to invite more students in Estonia since the number of stipendiaries had grown too large over the years. In 2003 the admission was organised but only a few new students arrived in Estonia as a result. In 2004 the Programme Council decided not to announce a public admission for Finno-Ugric 


\begin{tabular}{|l|c|c|}
\hline \multicolumn{1}{|c|}{ Ethnicity } & $\begin{array}{l}\text { KPP stipendiaries in } \\
\text { Estonia in 2000 }\end{array}$ & $\begin{array}{c}\text { KPP stipendiaries in } \\
\text { Estonia in 2004 }\end{array}$ \\
\hline Mari & 37 & 15 \\
\hline Udmurt & 24 & 12 \\
\hline Komi & $\begin{array}{c}\text { 16 (9 Komi-Zyryans and } 7 \\
\text { Komi-Permyaks) }\end{array}$ & $\begin{array}{c}\text { (2 Komi-Zyryans and 5 Komi } \\
\text { Permyaks) }\end{array}$ \\
\hline Mordvin & 7 (5 Erzyans and 2 Moksha) & 7 (5 Erzyans and 2 Moksha) \\
\hline Khanty & 3 & 2 \\
\hline Karelia & 5 & 4 \\
\hline Veps & 3 & 3 \\
\hline Ingrian-Finnish & 1 & 1 \\
\hline Livonian & 1 & - \\
\hline Nenets & 1 & 3 \\
\hline East-Estonian & 1 & $\mathbf{5 5}$ \\
\hline Total & $\mathbf{9 9}$ & 1 \\
\hline
\end{tabular}

Figure 1. The number of Kindred Peoples' Programme stipendiaries has consistently decreased over the years 1999-2004.

\begin{tabular}{|c|c|c|c|c|}
\hline Year & $\begin{array}{c}\text { Admission of new } \\
\text { stipendiaries }\end{array}$ & $\begin{array}{c}\text { BA level } \\
\text { graduates }\end{array}$ & $\begin{array}{c}\text { MA level } \\
\text { graduates }\end{array}$ & $\begin{array}{c}\text { PHD level } \\
\text { graduates }\end{array}$ \\
\hline 1999 & 15 & 12 & 4 & - \\
\hline 2000 & 9 & 17 & 5 & - \\
\hline 2001 & 10 & 3 & 3 & - \\
\hline 2002 & 0 & 6 & 5 & - \\
\hline 2003 & $3+2$ & 9 & 3 & 1 \\
\hline 2004 & $6+1$ & 6 & - & - \\
\hline Total & $\mathbf{4 6}$ & $\mathbf{5 3}$ & $\mathbf{2 0}$ & $\mathbf{1}$ \\
\hline
\end{tabular}

Figure 2. The number of positions is related to the number of graduates and those who have returned to their homeland. In 2003 there were 3 new stipendiaries and 2 students received stipendums for a one-year additional educational course; in 2004, 6 new and 1 student for a two-year additional educational course.

students coming to study in Estonia. The new stipendiaries of the Kindred Peoples' Programme were chosen from among the Finno-Ugric students already studying in Estonia and graduating from the BA level, thus providing them an opportunity to continue their studies on the MA level (see Figs. 1 and 2).

From the very start a group of Estonian students gathered around the Ariste centre and tried to think of opportunities for the Finno-Ugric students to spend their free time. In cooperation with NGO Fenno-Ugria Foundation the project 
Estonian-language discussion forum SURING (derived from Estonian phrases soome-ugri ring 'a Finno-Ugric circle' or suhtlemisring 'a circle of communication') was set up on the initiative of Helen Kõmmus. The purpose of the forum was to provide the Finno-Ugric students an opportunity to communicate with their fellow students (Estonian students and other foreign students studying in Estonia) outside the academic environment, to directly exchange knowledge about other cultures, to develop language and communication skills, share ideas and make new friends. In the 1999/2000 academic year, the SURING initiators organised tours to the Soomaa National Park, the exhibition building of the Estonian National Museum, and the Estonian Literary Museum; discussion events about the cultural societies of ethnic minorities in Estonia, the Unrepresented Nations' and Peoples' Organisation, the nationality policy of the Republic of Estonia and the possibility of nature religion in modern society; and also literary events on newer Estonian literature and the role of literature as ethnic policy on the example of literature in Võru variety, or the event on Livonian poetry. The organised events included also watching the documentary Mör vöš on the Udmurt traditional summer ritual, the Estonian historical comedy Minu Leninid (My Lenins), directed by Hardi Volmer, and the play Säärane mulk (What a Mulk) at the Vanalinnastuudio Theatre. The events included also the evening of Finno-Ugric folk games, the Erzyan event and the Udmurt event (the Udmurt students introduced the Udmurt wedding customs with a dance and singing performance), a discussion event of the All Souls' time, the celebration of St. Catherine's Day and the Christmas and New Year's celebration of Finno-Ugric students in Võru County. Paul Ariste's anniversary was celebrated in February by watching a documentary about Ariste and listening recollections about him by his former students. Vitali Romashkin, a student and the lead vocalist of the band Torama started the workshop of Erzyan folk songs.

SURING continued to be actively used in the 2000/2001 academic year. The autumn term began with sharing travel experience (Mare Kõiva talked about the first summer school of folklorists in the Udmurt Republic, Kauksi Ülle about seminars in Izhkar, Kozmodemyansk (Tsikmä), and the Sixth Congress of FinnoUgric authors in Saran). Also, a meeting with Forest Nenets author Yuri Vella and folklore collector and story-teller Tatva Logany was held; the Finno-Ugric students participated in the presentation of the biographical bibliography of Professor Paul Ariste (Professor Paul Ariste biobibliograafia 1921-2000) and visited the Karula National Park (getting acquainted with local history, nature, farm architecture and apiculture). The students also celebrated the anniversary of Mitrei Baatiev, founder of the Komi Republic (the event was organised by Komi MA student Ilia Mitiushev), kindred nations' days, the event celebrating the Erzyan language and culture and the traditional Mari Hero Day. The workshop of Erzyan folk songs continued its activities.

Although the Estonian discussion forum SURING ceased to exist since autumn 2001, the Ariste centre continued to organise the traditional sightseeing tours introducing Estonia, targeted mostly at the Finno-Ugric students who arrived in 
autumn. This time, the tour took them to West Estonia, including a visit to the C.R. Jakobson's Farm Museum and Suure-Jaani, Vändra, Tori and Pärnu.

For years, students have organised the sports games of Finno-Ugric students (initiated already in 1995). The organisers of this event agree that the new FinnoUgric students arriving in Estonia need direct communication with the older students of their kindred peoples, which can be best achieved at an informal sports event. The games have been supported by the Kindred Peoples' Programme and in recent years by the Ariste centre. The sports games of Finno-Ugric students were also held in November 2004.

The Ariste centre and the Fenno-Ugria Foundation cooperated in organising four seminar outings for Finno-Ugric students, which took place since autumn 1999 to spring 2002 (the exact dates being November 25-28, 1999; April 27-30, 2000; May 4-6, 2001; and May 9-12, 2002, organised jointly with MAFUN, Youth Association of Finno-Ugric Peoples). The seminar outings lasted for 3-4 days and were held in the Kiidi tourist farm in the Võru County. 30-40 students from universities in Tartu and Tallinn participated in each of the seminars, whereas preference was given to newly arrived first-year students. The aims of the seminars were to

(i) create better means to adapt to the academic life in Estonia (lectures on student traditions and rights in Estonia, the Kindred Peoples' Programme and FinnoUgric students, the rights and responsibilities of foreign students in Estonia: practical hints, residence and work permits for foreign students);

(ii) impart knowledge about the laws that the Estonian society is based on (lectures on the integration programme in Estonia and cultural autonomy, the history, development and laws of the Republic of Estonia, OSCE, PHARE, European Union, European Commission, Council of Europe, and EU-Russia relations);

(iii) develop skills to apply the acquired knowledge in the field in public as well as non-profit sphere (lectures on communication with foundations (applying for support), and the tendencies in rural life and agriculture today and in the future);

(iv) strengthen ethnic identity and sharing the experience of Estonians and other Finno-Ugric peoples in preserving identity and culture (lectures on Estonia and Estonians and how to "tame" them, the religious worldview of modern Estonians and the role of literature in the continuance of a nation, Finno-Ugrians, especially in Russia, the history of Fenno-Ugria, the opportunities of a small nation in contemporary world, Estonians and minority groups, Estonians in the world);

(v) enable students to meet the rejuvenated and renewed Youth Association of Finno-Ugric Peoples (MAFUN), which inspires students to take interest in the issues of their own homeland. This, in turn, should motivate them to return home after graduation and use their knowledge for the welfare of their own people. 
Since the Kindred Peoples' Programme decided not to invite new Finno-Ugric students to Estonia, the traditional seminar outing for Finno-Ugric students was cancelled in spring 2003. The stipendiaries of the Kindred Peoples' Programme were nevertheless offered a chance to participate in various seminars as active organisers. In January 29, 2003 the international seminar on the indigenous peoples' rights for land, organised by the Estonian Fund for Nature, was followed by a management course based on the traditions of indigenous peoples, where several students helped out as voluntary interpreters.

Cooperation with Finno-Ugric students was also sought by organisers of the seminar Multidisciplinary advice for travelling responsibly in the Finno-Ugric areas, held in the Võru County on April 28-May 1, 2003. The aim of this seminar was to promote cooperation in the field of ecotourism among the Finno-Ugrians by involving students of Finno-Ugric origin who study in Estonia. The organisers hoped that these seminars would motivate the Finno-Ugric students to return to their home towns or villages and find ways to apply ecotourism in their field of speciality. While preparing the seminar, the organisers contacted the Finno-Ugric students studying in Tartu and Tallinn and introduced them the principles of the project, emphasising their initiative in finding key persons in the target countries (their homelands). Unfortunately, the students remained rather passive in this issue - after the seminar the organisers admitted that they had expected greater initiative on the part of the students in establishing contacts with representatives of their home region.

A ten or so students of our kinfolk studying in Tartu participated in seminars on self-education and translating of young Finno-Ugric authors as both hosts and translators of the authors and translators of kindred people. Eight FinnoUgric students studying in Tartu were involved in the seminar Information Technology: The Finno-Ugric Way held in December 3-4, 2004 in Jäneda.

The Ariste centre and students of kinfolk alike have helped out at organising international conferences and congresses. On the request of the organisers of the Uku Masing Year in 1999, the Ariste centre mediated Finno-Ugric students as speakers at the international conference The World's Indigenous Cultures in the Work of Uku Masing (Julia Kuprina, ethnic Mari, spoke about the sacrificial and funeral traditions of the Mountain Mari, Khant Aleksei Obatin talked about the Khanty beliefs, and Udmurt Tatiana Minniakhmetova discussed the Udmurt folk religion). The students were also involved as the technical staff in the preparation and organisation of the 9th International Finno-Ugric Congress (Tartu 2000) and the 4th World Congress of the Finno-Ugric Peoples (Tallinn 2004).

In the course of the programme, the Proceedings of Paul Ariste Centre for Indigenous Finno-Ugric Peoples at the University of Tartu publishes educational materials, studies, works of general education, etc. on Uralic languages and cultures in different languages. The first volume of the series of proceedings is the overview Koola saamid (Sami of the Kola Peninsula, 2002) by Marju Sarv, 
PHD student of Uralic languages at the University of Tartu. The book is an introduction of the history of the Sami settled on the Kola Peninsula, Russia and dialects and variants of the Sami language spoken there. The publication entails an appendix with examples of language - so far unpublished original folk songs recorded by the author.

The second volume of the proceedings series is Мокшэрзянь мифологиясь (Mordvinian Mythology, 2002) the dictionary of Mordvin mythology in Moksha language by Tatiana Deviatkina. The Mordvin mythology consists of an introduction and a dictionary of 132 entry words. The introductory part of the book provides an overview of the language, history, research into mythology and the general characteristics of the folk religion. On the initiative of the Ariste centre, the language editors of the book were Tatiana Nadeikina and Anna Venchakova, two Moksha students studying Finno-Ugric languages at the University of Tartu. As the result of the joint project of the Ariste centre and the research group of media and folk religion of the Estonian Literary Museum, the work is available online (at http://www.folklore.ee/rl/folkte/sugri/mordva/ersa/myto2/koi-8).

The third volume of the series will be a book of Sami poetry, Saami luuleraamat, by Sami poets living in Finland, Sweden, Norway and Russia. The introduction to the book provides an overview of Sami literature. Since the poems are published in two languages, the book also serves as an educational material for teaching the Sami language as the closest kindred language of the Balto-Finnic languages.

The centre is also involved in the long-term multimedia project The Mordvin Ethnology, Folklore and Religion together with the research group of media and folk religion of the Estonian Literary Museum and the Estonian Folklore Archives, the Estonian National Museum and the Institute of Geography at the University of Tartu. The project (available at http://haldjas.folklore.ee/rl/folkte/ sugri/mordva/index.html) was initiated with a purpose to present interactive information and educational materials on the Mordvin culture, history, ethnography, religion and folklore in Estonian, Erzyan, Moksha and English language. The coordinator of the Ariste centre has been involved in the project as the main author, editor and illustrator. Most of the material included are so far unpublished studies, many of them recorded in the course of fieldwork by the authors. The project has prompted first research into various fields and the creation or improving academic terminology in ethnic Erzyan and Moksha languages, as well as enabled to involve Mordvin scholars as authors and translators and FinnoUgric students in Estonia as language editors and translators at the project.

During the period of its activity, the Ariste centre has supported various academic, educational, cultural and promotional projects connected with the Uralic indigenous peoples. With the centre's support three issues of Vita Studiosi, the newspaper of Finno-Ugric students (editor-in-chief Vassili Nikolaev, a Mari student) was published. The centre provided help in applying for support and editing the newspaper articles. 
The Ariste centre has also helped the Estonian Friends of Erzya-Moksha Society and NGO Fenno-Ugria Foundation in organising the annual Erzyan language and culture celebration day. At the seminar on Erzyan language held in April 2001, the coordinator of the Ariste centre presented the multimedia publication Mordvin Ethnology, Folklore and Folk Religion. On the festivity of Erzyan language held in the Tartu Literature House in 2002, the Erzyan and Moksha students read ethnic poetry and the Estonians sang Erzyan songs together with Vitali Romashkin, a stipendiary of the Kindred Peoples' Programme.

The Ariste centre also enabled Toomas Help, PHD student of the Chair of Estonian Language, University of Tartu, and Niina Aasmäe, lecturer at the Language Centre, University of Tartu to participate in the international forum Writing Erzyan Language in Latin Alphabet held in June 22-26, 2001 in St. Petersburg. In their presentation Toomas Help and Niina Aasmäe introduced their suggestions for using Latin alphabet in the Erzyan language. The aim of the forum was to work out common principles for the use of Latin alphabet in the applied Erzyan literary language in order to facilitate e-mail communication.

In March 2002, the centre launched the project The Bibliographical Database of Uralic Linguistics 1988-2000, which aim was the ongoing updating, improving and preparing of the URBIS (Uralic Bibliographical Survey) database in digital format. Until 2002 URBIS was compiled at the Tartu University Library (with Mare Onga as the project coordinator and executor). Since March 2002 the editing of Mare Onga's database became the responsibility of the Council of Kindred Peoples' Programme from provident funds at Paul Ariste Centre for Indigenous Finno-Ugric Peoples. URBIS is the direct successor of the section of linguistics of concise bibliography BSU (1917-1987) and presently contains entries on the printed publications and articles on linguistics and Uralic languages published in 1988-2000. URBIS is available online at the homepage of the Tartu University Library (http://www.utlib.ee/ee/kataloogid/biblioserver/index2.php? $\mathrm{id}=84)$.

After completing the URBIS project, Mare Onga has continued to work at the Ariste centre at the project Finno-Ugric linguistics in 2001-2003, which aims to compile a smaller follow-up database of literature on Finno-Ugric linguistics published in Estonia and in centres involved in Finno-Ugric studies in Russia and other East European countries. Mare Onga hopes to update the database with data on the year 2004. The Kindred Peoples' Programme continued to finance the project until December 2005.

The students of our kinfolk studying in Estonia have successfully participated in various projects financed by the Kindred Peoples' Programme. The online publication The Komi World published by the Department of Folkloristics of the Estonian Literary Museum (available at http://www.folklore.ee/rl/folkte/sugri/komi) has been compiled and edited by Nikolai Kuznetsov, PHD student of Estonian and Finno-Ugric languages at the University of Tartu. Natalia Kolegova, MA student of Estonian and Comparative Folklore is involved in the project as editor of Komi language. In the course of the three-year project (2001-2004), the portal of Komi 
culture will be constructed in the Komi, Estonian, English and Russian language, starting with the Komi language and later also in Estonian and other languages. Nikolai Kuznetsov is also the editor of O хантыйских шаманах (Khanty Shamanism, 2004), a collection of articles about Khanty shamans by V. Kulemzin, published by the Department of Folkloristics at the Estonian Literary Museum. Nikolai Kuznetsov and Irina Orekhova, student of Estonian and comparative folklore, were involved in raw translation of Komi and Udmurt texts for a project of publishing the anthology of Finno-Ugric classical poetry Kevadhommik. Soomeugri luuleklassikat II (A Spring Morning. Finno-Ugric Poetry Classics II, 2002). Uurali keelte sõnastik (Dictionary of Uralic Languages, 2004) published by the Information Centre of Finno-Ugric Peoples has involved six former and current stipendiaries of the Kindred Peoples' Programme as experts of the Erzyan, Moksha, Mountain and Meadow Mari, Komi and Udmurt languages.

Since one of the aims of the Kindred Peoples' Programme has been to avoid the disruption of the Finno-Ugric students' ties with their native people and homeland, the Ariste centre has offered students of Uralic indigenous origin opportunities to continue to foster their ethnic culture in Estonia. For this purpose the centre has invited speakers from the Uralic areas of indigenous regions - in spring 2000 Yuri Anduganov, professor of the Mari National University, delivered a series of lectures in Mari language on Mari language and culture and also a lecture in Estonian on research and teaching Finno-Ugric languages in the Republic of Mari El; in spring 2001 Tatiana Deviatkina, professor of the Saransk Pedagogical Institute held a series of lectures on Erzya-Moksha mythology (subject title FinnoUgric Folklore) at the University of Tartu; in 2002 Igor Uliashev, senior researcher at the Institute of Language, Literature and History of the Komi Science Centre (Uralic Department of the Russian Academy of Sciences) held a series of lectures on Komi folklore (subject title Finno-Ugric ethnology. Komi); and in 2003 Yuri Perevozchikov, lecturer of the Udmurt National University, held a series of lectures on contemporary ethnic processes in Udmurtia (subject title Finno-Ugric ethnology. Udmurts). In addition to the lectures Perevozchikov also showed a documentary on historical and cultural traditions in Udmurt towns and villages entitled Вот такая история... (It Was Like This...) and a television program on the international and cross-cultural relations in Udmurtia По соседству мы живем (Neighbourly We Live). The lecture series was graded pass/no pass for participating students.

In addition to foreign lecturers, the Finno-Ugric languages and cultures were also introduced by Finno-Ugrians living in Estonia. In spring term 2000 Erzyan Niina Aasmäe, lecturer of English language at the Language Centre of the University of Tartu and a former student of Paul Ariste held a lecture series on Erzyan language (subject title Distant kindred languages). The course was graded pass/ no pass for participating students.

The Ariste centre has also supported the programme stipendiaries' participation in international conferences and courses to prepare the students for academic, economical and political contacts with people of different cultural backgrounds. Owing to the financial support by the Kindred Peoples' Programme quite a number 


\begin{tabular}{|c|c|c|c|c|c|c|c|c|c|c|c|c|c|c|}
\hline D. & 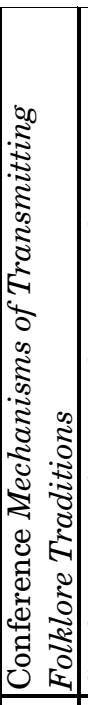 & 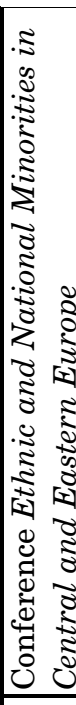 & 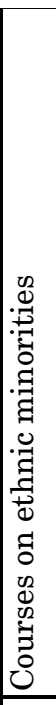 & 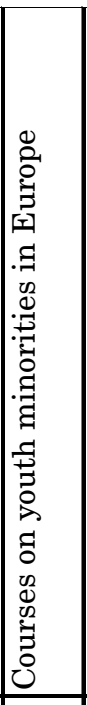 & 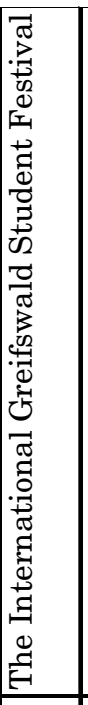 & 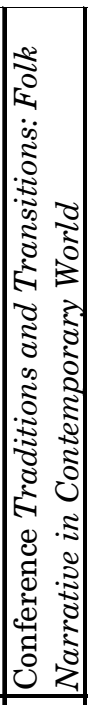 & 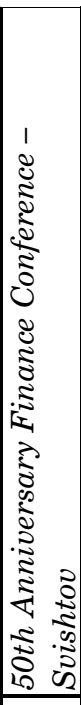 & 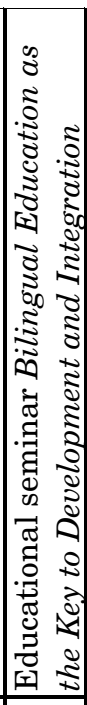 & 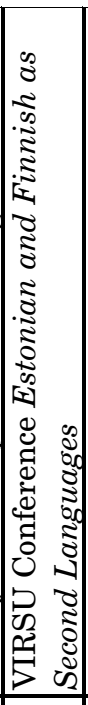 & 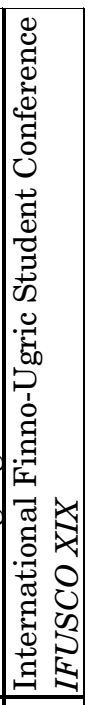 & 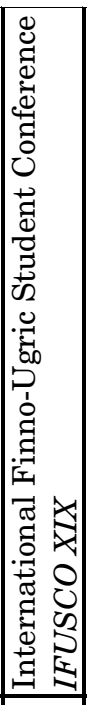 & 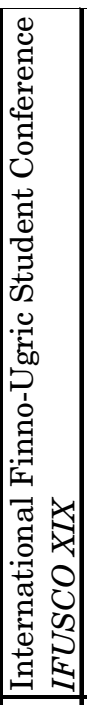 & 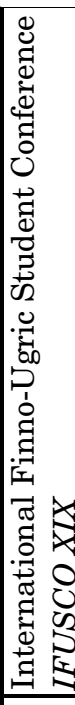 & 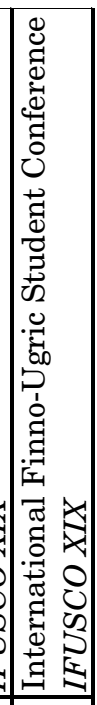 \\
\hline & 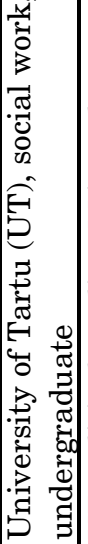 & 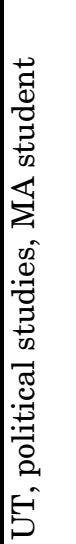 & 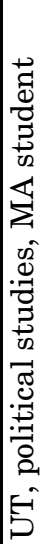 & 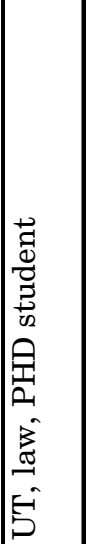 & 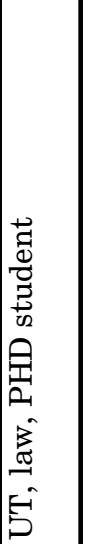 & 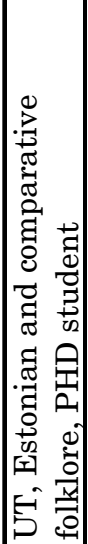 & 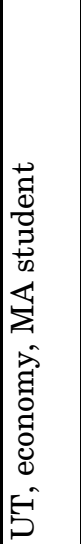 & 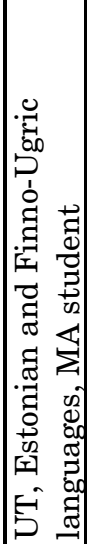 & 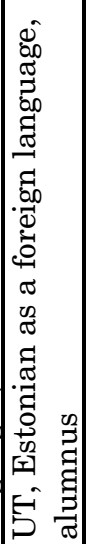 & 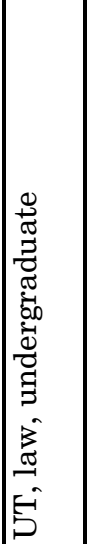 & 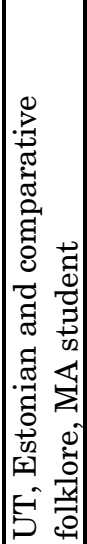 & 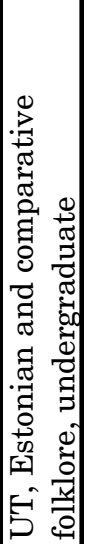 & 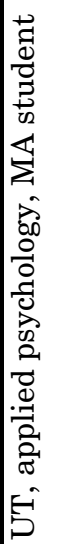 & 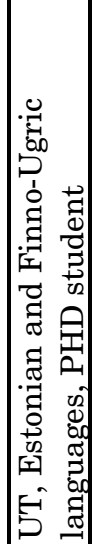 \\
\hline 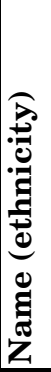 & 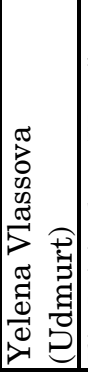 & 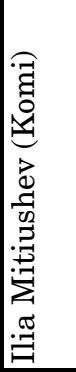 & 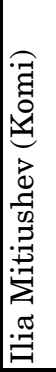 & 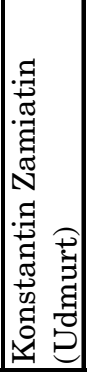 & 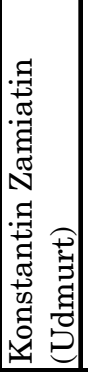 & 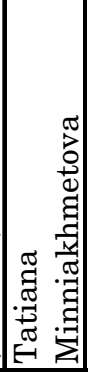 & 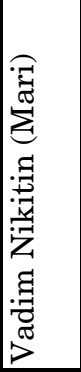 & 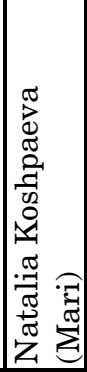 & 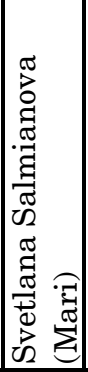 & 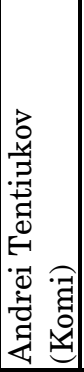 & 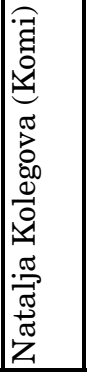 & 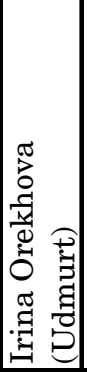 & 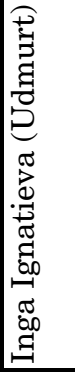 & 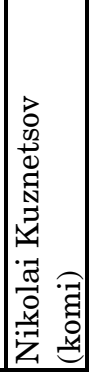 \\
\hline
\end{tabular}




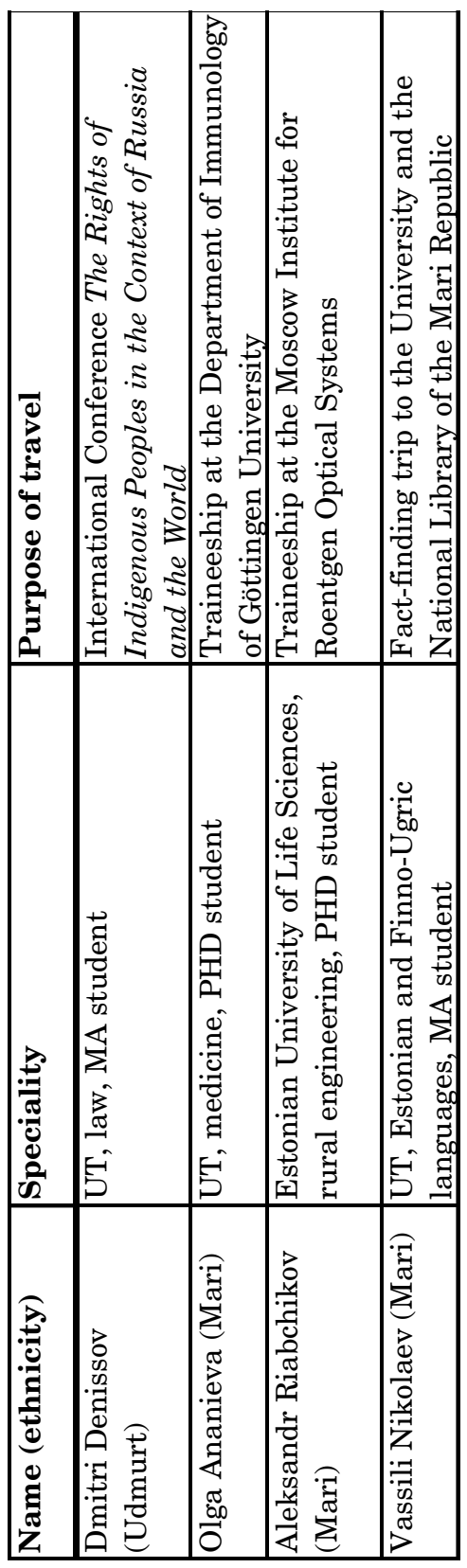

Table 3. The Ariste centre has supported the programme stipendiaries' participation in international conferences. 
of students have had the opportunity to take part in academic events in Europe and elsewhere (see Fig. 3).

The Kindred Peoples' Programme II (the state aid programme for supporting Uralic (Finno-Ugric and Samoyed) indigenous languages and cultures (20052009)) sanctioned by the Government of the Republic of Estonia on August 12, 2004 ensures the continuance of the Ariste centre's activities in the oncoming five years, since the centre's costs are covered from the programme's budget. The continuance of the programme makes it possible to continue to educate students of Uralic indigenous peoples in Estonian higher education schools. With reference to differences between the tertiary education system in Estonia (and Europe) and that valid in Russia, the centre will favour MA studies of the students graduating in Estonia and PHD studies of students graduating from universities in Russia.

The Kindred Peoples' Programme has enabled to continue Paul Ariste's life's work in educating a generation of intellectuals among the Finno-Ugric indigenous peoples in Russia. In the changing situation where the rights of indigenous peoples are increasingly finding acceptance in Russia, the Kindred Peoples' Programme has taken the responsibility to educate the ethnic language-speaking generation of intellectuals not only in the field of Finno-Ugric studies but also in law, journalism, political studies, psychology, information technology, etc. As a result, the Finno-Ugric countries will have not only intelligentsia in the humanities who have been educated in Estonia, but also educated lawyers, scientists, doctors and engineers, who will be joined with Estonia not only by kinship ties but also with fond memories from their student years. 